\title{
Effect of pH on compressive strength of some modification of mineral trioxide aggregate
}

\author{
Mohammad-Ali Saghiri ${ }^{1}$, Franklin Garcia-Godoy ${ }^{2}$, Armen Asatourian ${ }^{3}$, Mehrdad Lotfi ${ }^{4}$, Sepideh Banava ${ }^{5}$, \\ Kaveh Khezri-Boukani ${ }^{6}$
}

${ }^{1}$ BSc, MSc, PhD Assistant Professor, Department of Dental Material, Dental School, Member of Craniofacial Research center, Azad University (Tehran Branch) and Kamal Asgar Research Center (KARC) Tehran, Iran

${ }^{2}$ DDS, MS, PhD Professor, Bioscience Research Center, College of Dentistry, University of Tennessee Health Science Center, Memphis, TN, USA

${ }^{3}$ DDS visiting scientist, Kamal Asgar Research Center (KARC), Tehran, Iran

${ }^{4}$ DMD, MSc Professor, Research Center for Pharmaceutical Nanotechnology and Department of Endodontics, Dental Faculty, Tabriz University (Medical Sciences), Tabriz, Iran

${ }^{5}$ DMD, MSc Head and Assistant Professor, Department of Dental Material, Islamic Azad University (Tehran Branch), Tehran, Iran

${ }^{6} \mathrm{BSc}$, MSc Islamic Azad University, Tehran, Iran

Correspondence:

Department of Dental Material

Islamic Azad University

Tehran Branch, Tehran, Iran

sbanava@gmail.com

\begin{abstract}
Saghiri MA, Garcia-Godoy F, Asatourian A, Lotfi M, Banava S, KhezriBoukani K. Effect of $\mathrm{pH}$ on compressive strength of some modification of mineral trioxide aggregate. Med Oral Patol Oral Cir Bucal. 2013 Jul 1;18 (4):e714-20.
\end{abstract}

http://www.medicinaoral.com/medoralfree01/v18i4/medoralv18i4p714.pdf

Received: $16 / 11 / 2012$ Accepted: 16/02/2013

\begin{abstract}
Objectives: Recently, it was shown that NanoMTA improved the setting time and promoted a better hydration process which prevents washout and the dislodgment of this novel biomaterial in comparison with WTMA. This study analyzed the compressive strength of ProRoot WMTA (Dentsply), a NanoWMTA (Kamal Asgar Research Center), and Bioaggregate (Innovative Bioceramix) after its exposure to a range of environmental $\mathrm{pH}$ conditions during hydration.

Study Design: After mixing the cements under aseptic condition and based on the manufacturers' recommendations, the cements were condensed with moderate force using plugger into $9 \times 6 \mathrm{~mm}$ split molds. Each type of cement was then randomly divided into three groups $(n=10)$. Specimens were exposed to environments with $\mathrm{pH}$ values of 4.4, 7.4, or 10.4 for 3 days. Cement pellets were compressed by using an Instron testing machine. Values were recorded and compared. Data were analyzed by using one-way analysis of variance and a post hoc Tukey's test.

Results: After 3 days, the samples were solid when probed with an explorer before removing them from the molds. The greatest mean compressive strength $133.19 \pm 11.14 \mathrm{MPa}$ was observed after exposure to a $\mathrm{pH}$ value of 10.4 for NanoWMTA. The values decreased to $111.41 \pm 8.26 \mathrm{MPa}$ after exposure to a $\mathrm{pH}$ value of 4.4. Increasing of $\mathrm{pH}$ had
\end{abstract}


a significant effect on the compressive strength of the groups ( $\mathrm{p}<0.001)$. The mean compressive strength for the NanoWMTA was statistically higher than for ProRoot WMTA and Bioaggregate $(\mathrm{p}<0.001)$. Moreover, increasing of $\mathrm{pH}$ values had a significant effect on compressive strength of the experimental groups $(\mathrm{p}<0.001)$.

Conclusion: The compressive strength of NanoWMTA was significantly higher than WMTA and Bioaggregate; the more acidic the environmental $\mathrm{pH}$, the lower was the compressive strength.

Key words: Compressive strength, mineral trioxide aggregate, Nano.

\section{Introduction}

Mineral Trioxide Aggregate (MTA) showed better psychochemical properties including bioactivity and setting in the presence of moister in comparison with other similar materials (1). However, MTA has some disadvantages, such as prolonged setting time (1), poor handling attributes (2), absence of a known solvent for this material, and the difficulty of its removal after setting (3). Several studies made modifications to improve the properties of MTA, but some of them could not show effectiveness as it was expected (4).

Bioaggregate (BA; Innovative BioCeramix, Vancouver, Canada), a calcium silicate-based material, is a modified type of MTA (5). Most of the constituents are the same as that in white MTA (WMTA) except that BA is aluminum free (6). MTA and BA have same antibacterial behaviour (7), similar ability to prevent leakage (8) and same cell toxicity (6); however the push-out strength in furcal perforations repaired with WMTA was superior than those for BA in acidic condition; both cements are adversely affected by acidic $\mathrm{pH}$ (9) but there is no published study reporting the compressive strength of BA. $\mathrm{pH}$ changes produce different behaviors of MTA in various conditions; when MTA comes into contact with existing inflamed tissues it may be exposed to a low $\mathrm{pH}$ (as low as 5) (10), which can affect the sealing and physicochemical properties of MTA producing reduced bond strength to dentin (11). In contrast, higher $\mathrm{pH}(\mathrm{pH}$ 8.4) enhanced the MTA-dentin bond strength (12) and decreased leakage (13). The low $\mathrm{pH}$ of the surrounding tissues also affected the hydration reaction of MTA (14). Acidic environment reduced the surface hardness of MTA $(10,15,16)$ in combination with reduced compressive (17) and diametral strength (16). However, the hardness of MTA could be improved in a pH of 8.4 to 9.4 (18).

Moreover, compressive strength is an important factor when a material is placed in a cavity, which bears occlusal pressures in some applications like direct pulp capping (19), vital pulp therapies (20), and the placement of coronal barrier (21). Torabinjead et al. reported that the compressive strength of MTA increased during 3 weeks after placement in moist environment containing distilled water (22); meanwhile, other investigators have indicated that the amount of microleakage can be reduced when MTA is in contact with synthetic tissue fluid (13).
To accelerate the setting time and to speed up the hydration procedure of WMTA (23) and Portland cement, the size of particles have been made smaller (24). A new type of MTA in nano-size scale (NWMTA) has been recently patented in the USA (US Patent application No 13/211.880) with new characteristics such as fast setting time (less than 5 minutes). An investigation (25) showed its efficacy in physical and chemical changes which attributes to its increased surface area, resistance to acidic environment and less porosity.

The aim of present study was to compare the compressive strength of WMTA, BA and NWMTA in acidic and alkaline $\mathrm{pH}$ conditions. The null hypothesis was tested that the compressive strength value of tested cements would not be affected significantly when they were exposed to either acidic or alkaline situation.

\section{Material and Methods}

The compressive strengths of WMTA (Tooth-colored formula, ProRoot MTA, Dentsply, Tulsa, OK) and Bioaggregate (BA; Innovative BioCeramix, Vancouver, Canada) and Nano White Mineral Trioxide Aggregate (NWMTA; Kamal Asgar Research Center, US Pat \# $13 / 211880$ ) were determined according to the method recommended by the ISO 6876 (26). In brief, each material was mixed according the manufacturers' instructions and placed in one-end closed split stainless steel molds with $9 \mathrm{~mm}$ high and $6 \mathrm{~mm}$ wide. Thirty samples of each material were prepared and randomly divided into 3 groups of 10 specimens $(n=10)$ and exposed to different $\mathrm{pH}$ values. Synthetic tissue fluid (STF), prepared as $1.7 \mathrm{~g}$ of $\mathrm{KH}_{2} \mathrm{PO}_{4}, 11.8 \mathrm{~g}$ of $\mathrm{Na}_{2} \mathrm{HPO}_{4}, 80.0 \mathrm{~g}$ of $\mathrm{NaCl}$, and $2.0 \mathrm{~g}$ of $\mathrm{KCl}$ was prepared in $\mathrm{pH} 7.4$, in $\mathrm{pH} 4.4$ with butyric acid and $\mathrm{pH} 10.4$ with potassium hydroxide. Then, 10 samples of each material were wrapped in pieces of gauze soaked in STF buffered in butyric acid and potassium hydroxide at $\mathrm{pH} 4.4$ (group A for each material), 10 specimens at $\mathrm{pH} 7.4$ (group B for each material ) and finally 10 for $\mathrm{pH} 10.4$ (group $\mathrm{C}$ for each material), respectively. The pieces of gauze were refreshed every 24 hours (daily) to stabilize $\mathrm{pH}$ values $(12,18,25)$. The whole assembly was placed in an incubator with a constant temperature of $37^{\circ} \mathrm{C}$ and $95 \%$ humidity for 3 days $(12,18,25)$. Specimens were removed from the molds and placed lengthwise between the platens of an Instron 85215 (Instron Corp, Canton, 
MA) testing machine. All of the samples were solid when probed with an explorer before removing them from the molds. The samples were compressed at a rate of 1 millimeter/minutes, and the load at fracture was recorded in megapascals (MPa). Two specimens of $\mathrm{BA}$ in $\mathrm{pH}$ of 4.4 subgroups failed after being placed lengthwise between the platens of an Instron machine, underwent complete breakdown due to low mechanical strength therefore they were excluded from study. To calculate the compressive strength the formula below was used, using the values for height, diameter, weight and failure load. (Fig. 1).

$$
\text { Compressive strength }(\mathrm{MPa})=\frac{\text { Failure Load }}{\left(\frac{\text { width of plug }}{2}\right)^{2} \times \pi}
$$

One-way analysis of variance with a post hoc Tukey test was used to determine statistical differences among compressive strengths of the tested materials.

\section{Results}

The means value of compressive strength for experimental groups as following:

- WMTA: $63.78(\mathrm{pH}=4.4), 86.23(\mathrm{pH}=7.4)$, and 103.63 $(\mathrm{pH}=10.4)$.

- Bioaggregate: $10.88(\mathrm{pH}=4.4), 25.36(\mathrm{pH}=7.4)$, and $29.07(\mathrm{pH}=10.4)$.

- NanoWMTA: $111.41(\mathrm{pH}=4.4), 126.81(\mathrm{pH}=7.4)$, and 133.19 (pH=10.4). (Fig 2)

The greatest mean compressive strength $133.19 \pm 11.14$ $\mathrm{MPa}$ was observed after exposure to a $\mathrm{pH}$ value of 10.4 for NanoWMTA; however, the values decreased to $111.41 \pm 8.26 \mathrm{MPa}$ after exposure to a $\mathrm{pH}$ of 4.4. In-

Fig.1. Formula for calculating the resistance.

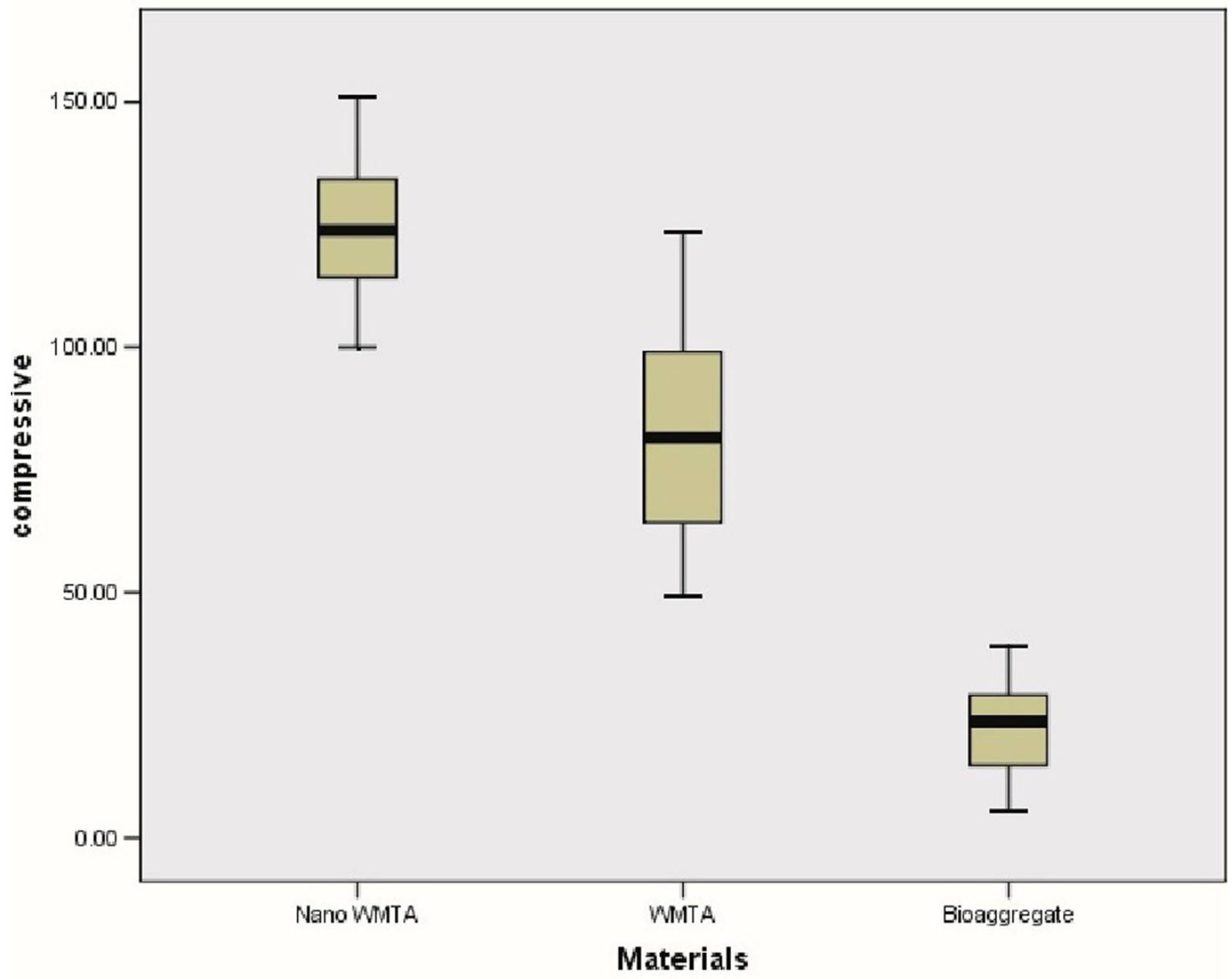

Fig. 2. Box plots of compressive strength (MPa) values for each type of cement as overall showing the axial amount of force for the compressive strength reached to crush the cement plug. 
creasing the $\mathrm{pH}$ had significant effects on the compressive strength of the all experimental groups $(\mathrm{p}<0.001)$. The mean compressive strength for the NanoWMTA was significantly more than WMTA and Bioaggregate $(p<0.001)$ (Table 1). Meanwhile, the statistical analyses revealed a significant interaction between the increase of the $\mathrm{pH}$ value and the compressive strength for all tested materials $(\mathrm{p}<0.001)($ Fig 3$)$.

\section{Discussion}

Nano-structured materials are defined as having a grain size not exceeding $100 \mathrm{~nm}$, typically a range between 5 to $50 \mathrm{~nm}$. Nano-structure addresses one of the key problems of endodontic cements such as setting time (27). Although the detailed mechanism of reaction of nano size powder needs to be determined for each specific cement system, experiments indicated that in practically all nano powders (whether oil- or water-based reaction), the kinetics of both absorption and desorption can be improved by the order of magnitude simply by reducing the grain size of the powder (28).

In the present study, we analyzed the compressive strength of two in comparison with new NanoWMTA which has been recently patented (27). By considering

Table 1. The ingredients of WMTA, Nano WMTA and Bioaggregate $(4,25,36)$.

\begin{tabular}{|c|c|c|c|c|c|}
\hline \multicolumn{6}{|c|}{ Cement ingredients } \\
\hline \multicolumn{2}{|c|}{ Nano WMTA } & \multicolumn{2}{|c|}{ WMTA } & \multicolumn{2}{|c|}{ Bioaggregate } \\
\hline Ingredient & $\begin{array}{l}\text { Molecular } \\
\text { Formula }\end{array}$ & Ingredient & $\begin{array}{l}\text { Molecular } \\
\text { Formula }\end{array}$ & Ingredient & $\begin{array}{c}\text { Molecular } \\
\text { Formula }\end{array}$ \\
\hline $\begin{array}{l}\text { Di-sodium } \\
\text { Hydrogen } \\
\text { Phosphate }\end{array}$ & $\mathrm{Na}_{2} \mathrm{HPO}_{4}$ & $\begin{array}{l}\text { Tri-calcium } \\
\text { Aluminate }\end{array}$ & $\mathrm{Ca}_{3} \mathrm{Al}_{2} \mathrm{O}_{6}$ & $\begin{array}{c}\text { Tri-calcium } \\
\text { Silicate }\end{array}$ & $\mathrm{Ca}_{3} \mathrm{SiO}_{5}$ \\
\hline Bismuth Oxide & $B i_{2} O_{3}$ & $\begin{array}{l}\text { Bismuth } \\
\text { Oxide }\end{array}$ & $\mathrm{Bi}_{2} \mathrm{O}_{3}$ & $\begin{array}{c}\text { Di-calcium } \\
\text { Silicate }\end{array}$ & $\mathrm{Ca}_{2} \mathrm{SiO}_{4}$ \\
\hline $\begin{array}{l}\text { Tri-calcium } \\
\text { Silicate }\end{array}$ & $\mathrm{Ca}_{3} \mathrm{SiO}_{5}$ & $\begin{array}{l}\text { Tri-calcium } \\
\text { Silicate }\end{array}$ & $\mathrm{Ca}_{3} \mathrm{SiO}_{5}$ & $\begin{array}{c}\text { hydroxyapa } \\
\text { tite }\end{array}$ & $\mathrm{Ca}_{10}\left(\mathrm{PO}_{4}\right) 6(\mathrm{OH})_{2}$ \\
\hline $\begin{array}{c}\text { Di-calcium } \\
\text { Silicate }\end{array}$ & $\mathrm{Ca}_{2} \mathrm{SiO}_{4}$ & $\begin{array}{c}\text { Di-calcium } \\
\text { Silicate }\end{array}$ & $\mathrm{Ca}_{2} \mathrm{SiO}_{4}$ & $\begin{array}{c}\text { calcium } \\
\text { silicate } \\
\text { oxide }\end{array}$ & $\mathrm{Ca}_{3}\left(\mathrm{SiO}_{4}\right) \mathrm{O}$ \\
\hline Calcium Sulfate & $\mathrm{CaSo}_{4}$ & $\begin{array}{l}\text { Bismuth } \\
\text { Oxide }\end{array}$ & $B i_{2} O_{3}$ & $\begin{array}{l}\text { Tantalum } \\
\text { oxide }\end{array}$ & $\mathbf{T i}_{2} \mathbf{O}_{5}$ \\
\hline Gypsum & $\begin{array}{c}\mathrm{CaSo}_{4} \cdot 2 \\
\mathrm{H}_{2} \mathrm{O}\end{array}$ & Gypsum & $\mathrm{CaSo}_{4} \cdot 2 \mathrm{H}_{2} \mathrm{O}$ & $\begin{array}{l}\text { calcium } \\
\text { silicate } \\
\text { oxide }\end{array}$ & $\left.\mathrm{Ca}_{3}(\mathrm{SiO} 4) \mathrm{O}\right)$ \\
\hline $\begin{array}{l}\text { Strontium } \\
\text { Carbonate }\end{array}$ & $\mathrm{SrCo}_{3}$ & & & $\begin{array}{l}\text { calcium } \\
\text { phosphate } \\
\text { silicate }\end{array}$ & $\begin{array}{l}\left(\text { alpha }=\mathrm{Ca}_{2} \mathrm{SiO}_{40}\right. \\
\left..05 \mathrm{Ca}_{3}\left(\mathrm{PO}_{4}\right) 2\right)\end{array}$ \\
\hline Zeolite & $M_{2} / \mathrm{nO} \cdot A_{12} C$ & $x \mathrm{SiO}_{2} \cdot \mathrm{yH}_{2} \mathrm{O}$ & & & \\
\hline $\begin{array}{l}\text { Tri-calcium } \\
\text { Aluminate }\end{array}$ & $\mathrm{Ca}_{3} \mathrm{Al}_{2} \mathrm{O}_{6}$ & & & & \\
\hline
\end{tabular}




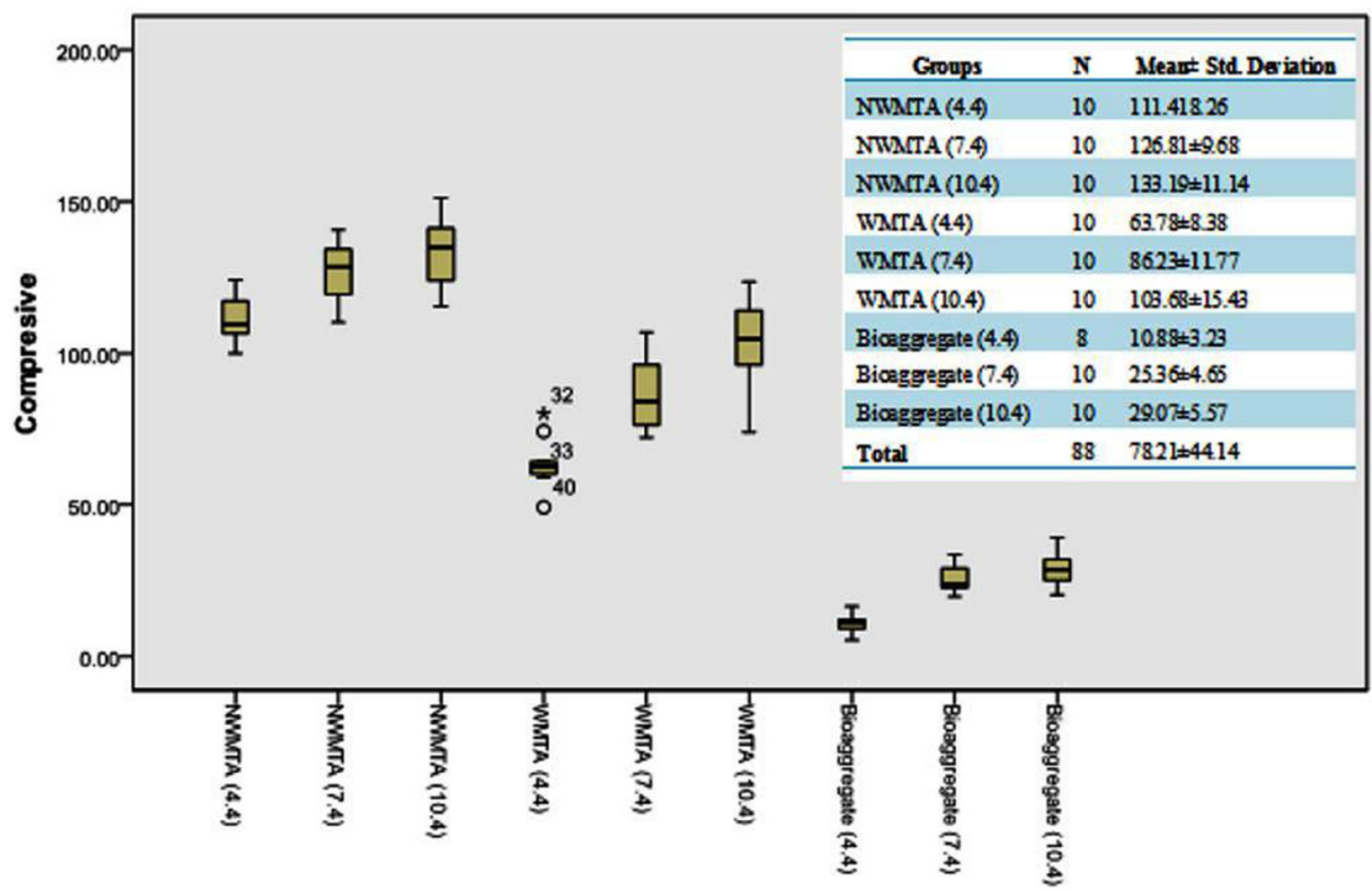

Fig. 3. Box plots of the compressive strength of each sub group of WMTA, Bioaggregate, and NanoWMTA in contact with different $\mathrm{pH}$ values.

the wide ranges of application of MTA (21) this factor plays an important role in the success of the treatment in some indications of this cement such as furcation perforations in which occlusal forces can be directly exposed to the applied cement (9). On the other hand, the long setting time of MTA can lead to additional costs when adding different additives such as $\mathrm{CaCl} 2$ (29) or $\mathrm{Na}_{2} \mathrm{HPO}_{4}$ (30) to prevent further washing-out and dislodgment (21). We examined the compressive strength of these three materials in three different conditions; acidic, neutral and alkaline environments. STF was used as a solution to mimic the physiological situation. In presence of infection and inflammation, the $\mathrm{pH}$ of tissue can be reduced (31). Furthermore, the $\mathrm{pH}$ value of most local anesthetics in cartridge form is purposefully low ( $\left.\mathrm{pH} 3 \frac{1}{2}-4\right)$, because the charged, acid form of the molecule is more stable (as is the vasoconstrictor) at a low $\mathrm{pH}$, and thus provides a longer shelf life (32). Therefore, butyric acid was used in the present study to simulate the effect of by-products of anaerobic bacterial metabolism (33) and stimulate clinical scenario. On the other hand, when MTA is used as an apical plug in open apex cases after the removal of calcium hydroxide, they may be placed in an alkaline $\mathrm{pH}$ environment and may alter the properties of MTA. Furthermore, all samples were condensed with a hand condenser and hand pressure due to the effectiveness of this method to prevent the formation of more voids (34).

Our results showed that acidic conditions had adverse effects in the compressive strength of these cements. Many studies reported similar results and the interference of acidic environment in the setting procedure (35), reduced strength (25), hardness, and the porosity of MTA $(10,13)$. BA had the lowest values in all $\mathrm{pH}$ conditions in comparison with WMTA and NWMTA. BA has very similar composition than MTA (36), but it is aluminum free and had different opaquers. Different radiopaquers can change the physical and chemical behavior of MTA (37) and decrease the compressive strength (38). Hashem et al. have investigated the dislodgement resistance of BA and MTA applied in furcation perforations (9). These authors have indicated that BA had less resistance in acidic situation in comparison with MTA cement; however, MTA was more influenced by acidic $\mathrm{pH}$ values than BA (9), which can suggest that BA cement is less applicable material especially in cases where occlusal forces are expected. The results showed an upward trend of the compressive strength values in each material in higher $\mathrm{pH}$ conditions and the greatest compressive strength values were observed in NWMTA at different $\mathrm{pH}$ values, 4.4, 7.4, 10.4, among others with $111.166,126.82$ and $133.19 \mathrm{MPa}$, respectively. BA had the lowest compressive strength particu- 
larly in $\mathrm{pH} 4.4$ around $10.88 \mathrm{MPa}$. In acidic condition, NanoWMTA exhibited the highest compressive value in comparison with other tested materials. The present study revealed that the greatest mean of compressive strength values were observed after exposure to a $\mathrm{pH}$ of 10.4. This finding is partly in agreement with the results of previous studies on the effect of alkaline $\mathrm{pH}$ on microhardness (18) and push bond strength of WMTA (12) which showed the higher surface hardness as well as less porosity and unhydrated structure in alkaline $\mathrm{pH}$ values. MTA might be exposed to a high-pH environment during treatment. Shokouhinejad et al. (11) showed an increase in the mean of push-out bond strength of WMTA as the $\mathrm{pH}$ was raised from 4.4 to 7.4 , which is consistent with the present results as the compressive strength of WMTA increased following exposure to $\mathrm{pH}$ 7.4 compared with pH 4.4. Tronstad et al. (39) showed that the $\mathrm{pH}$ of the most inner part of the circumpulpal dentin could chang the $\mathrm{pH}$ of its nearby environment from 11.1 to 12.2 after placing calcium hydroxide in the root canals.

The current study supports the previous study (25) stating that NWMTA had less porosity, better hydration, and good interlocking crystals than WMTA even in an acidic $\mathrm{pH}$. The present study also elucidated that NWMTA also kept its high strength in acidic environment compared to WMTA and BA. Therefore, $\mathrm{pH}$ alterations can jeopardize the structure of WMTA that may increase/decrease compressive strength. NanoWMTA showed better compressive strength value in acidic environments, however further studies regarding the cell interaction and biological behavior of this nano structure new cement are needed to address biological and bioactive responses.

\section{Conclusion}

According to present in-vitro study, following conclusions have been drawn:

- Acidic environment can drastically affect the compressive strength values of all tested materials. However, the increasing of $\mathrm{pH}$ in alkaline environment can enhance this property significantly in mentioned cements.

- In low $\mathrm{pH}$ conditions unfavorable structural changes can occur in the microsturcutre of cement materials which caused higher porosity in applied substances and eventually affect their compressive strength negatively. - NanoWMTA due to its higher compressive strength observed in all $\mathrm{pH}$ conditions can be suggested as a remarkable root end filling material, especially in situations in which the applied material might be exposed to acidic environments.

\section{Conflict of Interest}

The authors affirm that they have no financial affiliation or involvement with any commercial organization with direct financial interest in the subject or materials discussed in this manuscript and deny any conflicts of interest related to this study. M Ali Saghiri and Mehrdad Lotfi hold a US patent for this new endodontic cement.

\section{References}

1. Kogan P, He J, Glickman GN, Watanabe I. The effects of various additives on setting properties of MTA. J Endod. 2006;32:569-72.

2. Ber BS, Hatton JF, Stewart GP. Chemical modification of ProRoot MTA to improve handling characteristics and decrease setting time. J Endod. 2007;33:1231-4.

3. Boutsioukis C, Noula G, Lambrianidis T. Ex vivo study of the efficiency of two techniques for the removal of mineral trioxide aggregate used as a root canal filling material. J Endod. 2008;34:1239-42. 4. Torabinejad M, Parirokh M. Mineral trioxide aggregate: a comprehensive literature review--part II: leakage and biocompatibility investigations. J Endod. 2010;36:190-202.

5. Saghiri MA, Garcia-Godoy F, Gutmann JL, Lotfi M, Asatorian A, Ahmadi A. Push-out bond strength of a nano-modified mineral trioxide aggregate. Dent Traumatol. 2012. [Epub ahead of print]

6. De-Deus G, Canabarro A, Alves G, Linhares A, Senne MI, Granjeiro JM. Optimal cytocompatibility of a bioceramic nanoparticulate cement in primary human mesenchymal cells. J Endod. 2009;35:1387-90.

7. Zhang H, Pappen FG, Haapasalo M. Dentin enhances the antibacterial effect of mineral trioxide aggregate and Bioaggregate. $\mathrm{J}$ Endod. 2009;35:221-4.

8. Leal F, De-Deus G, Brandão C, Luna A, Fidel S, Souza E. Comparison of the root-end seal provided by bioceramic repair cements and White MTA. Int Endod J. 2011;44:662-8.

9. Hashem AAR, Wanees Amin SA. The effect of acidity on dislodgment resistance of mineral trioxide aggregate and Bioaggregate in furcation perforations: an in vitro comparative study. J Endod. 2012;38:245-9.

10. Namazikhah MS, Nekoofar MH, Sheykhrezae MS, Salariyeh S, Hayes SJ, Bryant ST, Mohammadi MM, Dummer PM. The effect of $\mathrm{pH}$ on surface hardness and microstructure of mineral trioxide aggregate. Int Endod J. 2008;41:108-16.

11. Shokouhinejad N, Nekoofar MH, Iravani A, Kharrazifard MJ, Dummer PM. Effect of acidic environment on the push-out bond strength of mineral trioxide aggregate. J Endod. 2010;36:871-4.

12. Saghiri MA, Shokouhinejad N, Lotfi M, Aminsobhani M, Saghiri AM. Push-out bond strength of mineral trioxide aggregate in the presence of alkaline pH. J Endod. 2010;36:1856-9.

13. Saghiri MA, Lotfi M, Saghiri AM, Vosoughhosseini S, Fatemi A, Shiezadeh V, Ranjkesh B. Effect of $\mathrm{pH}$ on sealing ability of white mineral trioxide aggregate as a root-end filling material. J Endod. 2008:34:1226-9.

14. Lee YL, Lee BS, Lin FH, Yun Lin A, Lan WH, Lin CP. Effects of physiological environments on the hydration behavior of mineral trioxide aggregate. Biomaterials. 2004;25:787-3.

15. Shie MY, Huang TH, Kao CT, Huang CH, Ding SJ. The effect of a physiologic solution $\mathrm{pH}$ on properties of white mineral trioxide aggregate. J Endod. 2009;35:98-101.

16. Nandini S, Natanasabapathy V, Shivanna S. Effect of various chemicals as solvents on the dissolution of set white mineral trioxide aggregate: an in vitro study. J Endod. 2010;36:135-8.

17. Watts JD, Holt DM, Beeson TJ, Kirkpatrick TC, Rutledge RE. Effects of $\mathrm{pH}$ and mixing agents on the temporal setting of tooth-colored and gray mineral trioxide aggregate. J Endod. 2007;33:970-3.

18. Saghiri MA, Lotfi M, Saghiri AM, Vosoughhosseini S, Aeinehchi M, Ranjkesh B. Scanning electron micrograph and surface hardness of mineral trioxide aggregate in the presence of alkaline $\mathrm{pH}$. J Endod. 2009;35:706-10.

19. Zarrabi MH, Javidi M, Jafarian AH, Joushan B. Histologic assessment of human pulp response to capping with mineral trioxide aggregate and a novel endodontic cement. J Endod. 2010;36:177881.

20. Asgary S, Eghbal MJ. The effect of pulpotomy using a calcium- 
enriched mixture cement versus one-visit root canal therapy on postoperative pain relief in irreversible pulpitis: a randomized clinical trial. Odontology. 2010;98:126-33.

21. Roberts HW, Toth JM, Berzins DW, Charlton DG. Mineral trioxide aggregate material use in endodontic treatment: a review of the literature. Dental Materials. 2008;24:149-64.

22. Torabinejad M, Hong CU, McDonald F, Pitt Ford TR. Physical and chemical properties of a new root-end filling material. J Endod. 1995;21:349-53.

23. Komabayashi T, Spangberg LS. Comparative analysis of the particle size and shape of commercially available mineral trioxide aggregates and Portland cement: a study with a flow particle image analyzer. J Endod. 2008;34:94-8.

24. Tennis PD, Jennings HM. A model for two types of calcium silicate hydrate in the microstructure of Portland cement pastes. Cement and Concrete Res. 2000;30:855-3.

25. Saghiri MA, Asgar K, Lotfi M, Garcia-Godoy F. Nanomodification of Mineral Trioxide Aggregate for enhanced physiochemical properties. Int J Endod. 2012;45:979-88.

26. International Organization for Standardization. Specification for dental root canal sealing materials. ISO 6876. London: British Standards Institution, 2001.

27. Saghiri MA, Lotfi M, Aghili H, Dental Cement Composition. US Patent Appl 13/211880 USPTO Patent. 2012

28. Skibsted J, Hall C. Characterization of cement minerals, cements and their reaction products at the atomic and nano scale. Cement and Concrete Res. 2008;38:205-25.

29. Antunes Bortoluzzi E, Juárez Broon N, Antonio Hungaro Duarte M, de Oliveira Demarchi ACC, Monteiro Bramante C. The use of a setting accelerator and its effect on $\mathrm{pH}$ and calcium ion release of mineral trioxide aggregate and white Portland cement. J Endod. 2006;32:1194-7.

30. Huang TH, Shie MY, Kao CT, Ding SJ. The effect of setting accelerator on properties of mineral trioxide aggregate. J Endod. 2008;34:590-3.

31. Nekoofar MH, Namazikhah MS, Sheykhrezae MS, Mohammadi MM, Kazemi A, Aseeley Z, et al. pH of pus collected from periapical abscesses. Int Endod J. 2009;42:534-8.

32. SF Malamed. Handbook of Local Anesthesia 3rd edn. St Louis: Mosby: 1990:1-332.

33. Eftimiadi C, Buzzi E, Tonetti M, Buffa P, Buffa D, Van Steenbergen M, de Graaff J, Botta GA. Short-chain fatty acids produced by anaerobic bacteria alter the physiological responses of human neutrophils to chemotactic peptide. J Infect. 1987;14:43-53.

34. Aminoshariae A, Hartwell GR, Moon PC. Placement of mineral trioxide aggregate using two different techniques. J Endod. 2003;29:679-82.

35. Saghiri MA, Asgar K, Lotfi M, Karamifar K, Neelakantan P, Ricci JL. Application of mercury intrusion porosimetry for studying the porosity of mineral trioxide aggregate at two different $\mathrm{pH}$. Acta Odontol Scand. 2012;70:78-82.

36. Park JW, Hong SH, Kim JH, Lee SJ, Shin SJ. X-ray diffraction analysis of White ProRoot MTA and Diadent BioAggregate. Oral Surg Oral Med Oral Pathol Oral Radiol Endod. 2010;109:155-8.

37. Coomaraswamy KS, Lumley PJ, Hofmann MP. Effect of bismuth oxide radioopacifier content on the material properties of an endodontic Portland cement-based (MTA-like) system. J Endod. 2007;33:295-8.

38. Camilleri J. Evaluation of the physical properties of an endodontic Portland cement incorporating alternative radiopacifiers used as root-end filling material. Int Endod J. 2010;43:231-40.

39. Tronstad L, Andreasen JO, Hasselgren G, Kristerson L, Riis I. pH changes in dental tissues after root canal filling with calcium hydroxide. J Endod. 1981;7:17-21.

Acknowledgments

We are indebted to Professor Shahram Azimi for providing some raw materials and their contributions to this research. Special thanks to Dr.Maryam Elyasi for reviewing manuscript. 